\title{
Global Corporate Tax Rate Competition Who Pays the Bill?
}

\author{
Gilda Almeida \\ University of Miami Law School, J.D. Candidate, 2019, Miami, U.S.A. \\ University of Miami Law School, LL.M. in Arbitration Candidate, 2019, Miami, U.S.A. \\ Georgetown University Law School, LL.M. in Taxation, 2017, Washington, U.S.A. \\ Georgetown University Law School, Certification in International Taxation 2017, Washington, U.S.A. \\ Universidade Candido Mendes, 1986,Brazil, Ga443@georgetown.edu
}

\begin{abstract}
Countries heavily rely on tax revenue for their welfare programs, which aim to reduce inequalities. Taxes are countries' main sources of revenue and provide funding for governmental expenditures. A country's spending is usually divided into categories: mandatory, discretionary, and interest on debt expenditures. These include assistance programs, such as the United States' Medicaid program, the Supplemental Nutrition Program (so-called foods stamps), and the Temporary Assistance for Needy Families program. The United States lowered its U.S. corporate income tax rate from 35\% to 21\% in 2018, after the enactment of the United States Tax Cuts and Jobs Act. Similarly, members of the Organization for Economic and Co-operation and Development (OECD) lowered their corporate statutory tax from their 2000 average rate of $28.6 \%$ to $21.4 \%$ in 2018 . In the international context, state-to-state tax arbitration is implemented by OECD members to provide multinationals with double tax relief. In contrast, individuals do not benefit from a similar tax reduction. The United States' highest marginal income tax rate was reduced from $39.60 \%$ to $37 \%$ in 2018 , whereas $0.5 \%$ was the average reduction implemented for individuals by OECD members from 2000 to 2017 . This paper analyzes whether states expect private corporations to undertake more social responsibility when considering tax benefits. States' examination of corporates' social responsibility includes whether private social accountabilities align with corporations' profit-oriented natures as well as state interest in public welfare. Furthermore, this paper examines states' alternative sources of revenues that could balance out the effects of the reduction of corporations' tax rates and other granted benefits, including tax arbitration for multinationals' double tax relief.
\end{abstract}

KEYWORDS: federal taxes, OECD, tax arbitration, welfare program, tax revenue, corporate tax, income tax, Tax Cuts and Jobs Act, individual taxes, MAP arbitration, alternative sources of revenue, mutual agreement procedure, international taxation, Base Erosion Profit Shifting (BEPS), Action 14, Section 482, arm's length

\section{Introduction}

Taxes are countries' main sources of revenue and support governments' expenditures. A country's spending is usually divided into categories - mandatory, discretionary, and interest on debt expenditures - and these include assistance programs such as the United States' Medicaid program, the Supplemental Nutrition Program (so-called foods stamps), and the Temporary Assistance for Needy Families. Countries rely heavily on tax revenue for their welfare programs in order to reduce inequalities. With the enactment of the United States Tax Cuts and Jobs Act, the country lowered the U.S. corporate income tax rate from $35 \%$ in 2017 to $21 \%$ in 2018 (USCS USSALT 2017-115-9; Tax Policy Center 2017).

Similarly, members of the Organization for Economic Cooperation and Development (OECD) lowered their corporate statutory tax rate from an average of $28.6 \%$ in 2000 to $21.4 \%$ in 2018 (OECD 2019). In the international context, state-to-state tax arbitration is implemented by OECD members, including the U.S., to provide multinationals with double tax relief (U.S. Department of Treasure, United States Model Income Tax Convention). The tax arbitration is available to the taxpayer as a result of tax treaties. The arbitration award determines how two jurisdictions allocate taxpayer's tax rights when both states claim they are entitled to it.

In contrast, individuals do not benefit from a similar tax reduction. The highest marginal income tax rate in the U.S. was reduced from $39.60 \%$ to $37 \%$ in 2018 (USCS USSALT 2017-115-9; Tax Policy Center 2017), whereas OECD members decreased individual tax rates by $0.5 \%$ from 2000 to 2017 (OECD 2019; 2018, 7). 
This paper examines whether states expect private corporations to undertake more social responsibility when considering the tax benefits they grant. The paper also considers whether this presumption is consistent with corporations' profit-seeking nature and states' interest in public welfare interest. Furthermore, this paper examines states' alternative sources of revenues that could balance out the effects of a reduction of tax rates for corporations and other granted benefits, including tax arbitration for multinationals' double tax relief.

\section{It is Corporate's World}

In the past, individuals used business structures, including corporations, to shield themselves from personal liability. Back then, it was unforeseen that corporations would become today's complex and powerful structures, and such large players in the political, economic, and social arenas.

With increasing globalization, corporations have expanded internationally, acquiring power equivalent to that of states (Riken 2009, 28). Multinationals now exercise their enormous bargaining power, seeking to globally maximize profitability by lobbying for economic and legal environments that better suit their needs. On the other hand, states, concentrating on their economic growth, often offer corporations attractive benefits to avoid a capital outflow.

A state, however, must act according to its national interests. Lowering the national unemployment rate and gathering the projected tax revenue for budgeted expenses are among significant concerns of a state. A state goal, however, may be directly affected - positively or negatively - by the manner in which a corporation positions itself in a specific jurisdiction, as public and private objectives may not necessarily align. Corporations' strategies are global and include sophisticated tax planning in order to reach a low effective tax rate and maximize profits. To that end, multinationals may fluctuate levels of investment or their employment rate in a country.

On the other hand, a state assumes that a tax cut accelerates its economic growth, sparking a higher level of employment that can lead to more consumption and expansion of its tax base. Therefore, in theory, a state would have a broader tax base, including taxes over wages, and corporations' boosted taxable income. Nonetheless, this projection becomes challenging when other states offer similar or more advantageous tax benefits to multinationals. As a result, a state must engage in a comprehensive strategy, in addition to offering a favorable environment for multinationals. Lowering state expenditures and seeking alternative sources of revenue can help neutralize a possible loss of revenue and deficit difficulties.

Tax incentives can be even more challenging in developing states because they are still quite dependent on a large lump of investment for building up their basic infrastructures, such as public health, electricity, sanitary sewer systems, and environmental impact management. As a result, those states must carefully balance the benefits of offering multinationals tax benefits and maintaining their tax systems in place to improve their welfare programs and reduce poverty (Zolt 2013, 647).

It is known that private and public interests must be balanced. However, there is difficulty in counterbalancing a multinational's global strategy with the interests of each state since a multinational's goal is to maximize its global profitability with the less possible effective tax rate, while a state's goal is to ensure efficiency, without shrinking its tax base.

\section{Then, Should Multinationals Pay Twice?}

In order to attract investments, states sign bilateral and multilateral treaties consenting to mandatory and binding tax arbitration to prevent multinationals from exposure to a double tax burden. The treaty arbitration provision is an update to the mutual agreement procedure (MAP) clause, which provides for state-to-state negotiation among the treaty partners for better protection of taxpayers' rights when a corporation is taxed twice for the same event.

The long and unsuccessful non-binding MAP treaty provision, aligned to factors that include multinationals' challenge in complying and applying a non-uniform global transfer pricing rules - 
that could culminate with relevant tax adjustments in more than one jurisdiction over the same event -triggered a global discussion.

Seeking a more uniform approach to international taxation and a better balance of public and private interests, the OECD launched 15 action plans under its the Base Erosion and Profit Shifting Project (BEPS). Action 14 calls for definitive tax arbitration after a non-settled MAP. For example, in 2016 the United States, an OECD member, committed itself to the BEPS Project and incorporated an arbitration provision, referring cases to binding and mandatory arbitration after two years of non-settled negotiations (U.S. Department of Treasure 2019). To date, state-to-state tax arbitration is the only effective way to solve multinationals' double tax burden.

Since multinationals' strategies are global, states that grant them access to treaty arbitration could hypothetically be awarded a greater inflow of investment. The combination of a low effective tax rate and lack of risk of double taxation in transfer pricing matters grant multinationals the certainty of a stable legal and economic environment for their investments.

However, the tax arbitration model provides states - especially developing jurisdictions with less certainty. A binding and mandatory arbitration provision limits tax sovereignty and can subject states to undesirable consequences, including the concession of tax credits, exceptions, or allowances. Furthermore, due to the confidential nature of state-to-state tax arbitration and its early stage, a state cannot forecast the economic or social impact of such a provision.

Thus, a state faces the dilemma of choosing between the risk of a capital outflow by not benefitting multinationals with the certainty of double tax relief or making an irreversible decision that could lead to a material loss of tax revenue. Again, it becomes a challenge of balancing public and private interests when the public party plans on a strictly local basis, and the private party has a global strategy. The balance must be constantly readjusted since societies and multinationals continuously evolve and grow (Riken 2009, 32).

A state - limited within its territory - requires effective ways to benefit its citizens (Petersmann 2013, 209); therefore, attracting multinationals' investments is also a relevant national interest. However, the granting of benefits may not be enough to ensure multinationals' long-term commitment due to their global strategies and the competitive international tax market. There may be another state offering a multinational a more significant deal.

In conclusion, a state - especially a developing one - should not engage in a worldwide tax competition without the certainty that its tax base would not be depleted. A tax benefit - including a reduction of the corporate tax rate and the certainty of double tax relief - should be a product of a private party's commitment to long-term investment in a country. Establishing clear rules for the private and public parties benefits both, leading to more certainty and efficiency.

However, multinationals - as global units - should not have a cross-border event taxed twice. The double-tax burden interferes with a corporation's ability to grow economically and its reinvesting power. Multinationals struggle to manage a large volume of compliance and reporting demands by different states and multilateral treaties. Granting multinationals with certainty and predictability can boost their confidence to make greater global investments and expand markets.

\section{States' Alternative Sources of Revenue}

A state needs to identify alternative sources of revenue to offset the revenue cost of substantially cutting down a corporate statutory rate and granting other benefits, including tax arbitration. Increasing individual income or capital gain tax rates are options for balancing out a state's finances; however, high net-worth individuals engage in sophisticated tax planning and may also not be affected by the rise. Those that have taxes withheld from their payrolls would be the most affected. However, a state is less likely to impose heavier taxation on wages as this would be an unpopular measure for a class of taxpayers that has a limited ability to pay more.

Other alternative sources of financing include taxation on consumption and environmentally harmful activities as well as property taxes (European Commission 2018, 85).

Angola, as an example, recently enacted a modern consumption tax, inspired by the valueadded tax (VAT) system. Angola's main objectives are achieving economic stability and attracting 
multinationals by offering them more effective tax management, fiscal neutrality, and predictability. The Angola "SLIM VAT" is to be fully implemented in 2021 (PressReader Jornal de Economia e Finanças 2019; Assembléia Nacional de Angola 2019). Although it is initially only mandatory for large corporations, other corporations may elect for it during the two-year transition period. Its standard rate is $14 \%$ on supplies of goods, services, and imports.

It is important to note that Angola - and most developing states - has had its tax base diminished by a hidden economy, a consequence of a high rate and complex corporate income tax. A simplified tax model should boost the economy, bringing out underground businesses and maximizing tax collection at a reduced state cost.

Including a state's informal economy is a great way to efficiently enlarge and maintain a state's tax base. Similarly, other developing countries may benefit from a VAT-type system.

\section{Conclusions}

In today's economy, where corporations are global and states are limited to their jurisdictions, the state is the more vulnerable party. Multinationals are facing an increased risk of double taxation due to mismatches in states' tax regulations and increased exchange of information between states as a consequence of multilateral tax treaties providing for more transparency. Furthermore, multinationals are being exposed to simultaneous audits and receiving tax adjustments that are large enough to hurt their finances and reputation.

On the other hand, a state cannot sustain a progressive corporate tax rate reduction without impacting its finances and social responsibilities. It is the state's duty to provide for its citizens' welfare, which includes addressing population inequalities and poverty and investing in state infrastructures. There should be no misconception that a private entity could take over these responsibilities. It is also a state's burden to implement measures that can increase and sustain its tax base and shrink its expenditures to offset any tax benefit granted.

In a globalized economy, a tax benefit granted by a state generates a competitive reaction from other states. States have to work on a mutual solution to creating shared economic growth. No formula fits every state, but all states together may have to participate in promoting a more neutral global tax system that better balances public and private interests.

\section{References}

Assembléia Nacional de Angola. 2019. “Implementacao do IVA é Consensual” Accessed March $4^{\text {th }}, 2019$. http://www.parlamento.ao/noticias/iii-legislatura/-/blogs/.

European Commission. 2018. "Tax Policies in the European Union. European Union Tax Policy Report.” Luxembourg Publications Office of the European Union. ISBN 978-92-79-96692-7:85.

Organization for Economic Co-operation and Development (OECD). 2018. "Taxing Wages." Paris: OECD Publishing. Accessed March 4 ${ }^{\text {th }}, \quad 2019$. https://read.oecd-ilibrary.org/taxation/taxing-wages-2018_tax_wages-2018en\#page7.

Organization for Economic Co-operation and Development (OECD). 2019. "Statutory Corporate Income Tax Rates." Accessed March $4^{\text {th }}, 2019$. https://stats.oecd.org/Index.aspx?DataSetCode=CTS_CIT.

Petersmann, Ernst-Ulrich. 2013. Fragmentation and Judicialization of International Law as Dialectic Strategies for Reforming International Economic Law, 5 Trade L. \& Dev. 209(5) 255: 209.

PressReader - Jornal de Economia e Finanças. January 25 , 2019. "Deputados Aprovam Código Penal e do IVA por Unanimidade." Accessed March 4 ${ }^{\text {th }}, 2019$. https://www.pressreader.com.

Riken, Susanna K. 2009. "Corporations are people too: a Multi-dimensional approach to the Corporate Personhood Puzzle." 15 Fordham J. Corp. \& Fin. L. 97:28-32.

Tax Policy Center. 2017, February 14. "Corporate Top Tax rate and Bracket." Accessed March $4{ }^{\text {th }}, 2019$. https://www.taxpolicycenter.org/statistics/corporate-top-tax-rate-and-bracket.

Tax Policy Center. 2018, February 5. "Detailed Individual Income Tax Parameters (Including Brackets) 1944-Present." Accessed March 4 ${ }^{\text {th }}$, 2019. https://www.taxpolicycenter.org/statistics/detailed-individual-income-taxparameters-including-brackets-1944-present.

United States Department of the Treasury. 2019. "Unites States Model Income Tax Convention.” Accessed March $4^{\text {th }}$, 2019. https://www.treasury.gov/resource-center/tax-policy/treaties/documents/treaty-us\%20model-2016.pdf.

USCS USSALT 2017-115-9, Current through PL 115-334, 12/20/2018. LEXIS Law Publishing. Accessed March $4^{\text {th }}, 2019$.

Zolt, Eric M. 2013. Inequality in America: Challenges for Tax and Spending Policies, 66 Tax L. Rev. 641, $694: 647$. 